Article

\title{
Sustainability of Youth Careers in Romania-Study on the Correlation of Students' Personal Interests with the Selected University Field of Study
}

\author{
Lucian-Ionel Cioca ${ }^{1,2}$ (D) and Mihaela Laura Bratu $1, * \mathbb{D}$ \\ 1 Department of Industrial Engineering and Management, Faculty of Engineering, Lucian Blaga University \\ of Sibiu, 550024 Sibiu, Romania; lucian.cioca@ulbsibiu.ro \\ 2 Department of Technical Sciences, Academy of Romanian Scientists, 010071 Bucharest, Romania \\ * Correspondence: ybratulaura@gmail.com; Tel.: +40-745-376-880
}

Citation: Cioca, L.-I.; Bratu, M.L. Sustainability of Youth Careers in Romania-Study on the Correlation of Students' Personal Interests with the Selected University Field of Study. Sustainability 2021, 13, 229. https:// doi.org/10.3390/su13010229

Received: 16 October 2020 Accepted: 24 December 2020 Published: 29 December 2020

Publisher's Note: MDPI stays neutral with regard to jurisdictional clai$\mathrm{ms}$ in published maps and institutional affiliations.

Copyright: (C) 2020 by the authors. Licensee MDPI, Basel, Switzerland. This article is an open access article distributed under the terms and conditions of the Creative Commons Attribution (CC BY) license (https:// creativecommons.org/licenses/by/ $4.0 /)$.

\begin{abstract}
Sustainable use of resources is an act of social responsibility, in which all the factors that benefit or exploit that resource are involved. Education, with its most important goal-finding a place in the labor market in the form of a career-is a process that involves multiple financial, human and institutional resources. The present study analyzes to what extent the careers that young people in Romania build correlate with their personal interests. Using the Holland Test, the interests of a group of engineering students were identified. It was observed that there are three typologies of people: Those who have chosen their field of study according to their interests, those who are interested in interdisciplinary fields of which engineering is a part and the third category, who have no interest in the field of engineering. The percentages of the three categories are approximately equal, which should determine the change of educational policies in Romania, in the sense of promoting and practicing career guidance for the early discovery of young people's interests and the sustainable convergence of all resources towards them.
\end{abstract}

Keywords: sustainable career; Holland test; summative code; engineers' interests; RIASEC

\section{Introduction}

Sustainability is development that meets the needs of the present without compromising the ability of future generations to meet their own needs [1]. The United Nations has included sustainability in its list of priorities since 1992 and in 2018 it resumes the idea of sustainability, associated with climate change [2]. Climate change is becoming more acute, including in terms of individual perception [3]. The individual's personal perception of sustainability is often reduced to climate change, selective waste collection, green energy, forest management $[4,5]$ and so on. However, sustainability is a concept that applies to all human needs and in all areas of activity.

Currently, the concept of sustainability has been debated worldwide for the last 30 years and has multiple meanings [6]. The concept of sustainability has expanded and can be found on three levels: economic sustainability [7], political sustainability and social sustainability $[8,9]$ but at the same time, sustainability can be associated with any system of activity, including education.

Research on the education system approaches the concept of sustainability from two perspectives - first, through which education for a sustainable environment refers to educational policies for the development of knowledge, skills and values, which support sustainable development and economic sustainability [10-12]. The second perspective of the education system related to sustainability associates the concept of education sustainability with the concept of social sustainability [13].

Another approach to the concept of sustainability, which can be extended to the education system, can be made from the perspective of consistency: external and internal 
sustainability [8]. The external sustainability of the educational system can be explained from the perspective of social sustainability, through the long-term impact on the environment and sustainable development $[14,15]$. The internal sustainability of the education system refers to the impact on the sustainable life of young people, the balance between professional and personal life [16].

Following the models analyzed above, Holdsworth and Thomas [17] propose another theory on this subject. There are three approaches concerning these concepts: Education about sustainable development, education for sustainable development and sustainability as education (sustainability education). This model has similarities with the one that deals with sustainability and education from the perspective of consistency.

In conclusion, sustainability has a defining impact on the educational system, at all levels of social organization (economic, political, social), on the structure (through educational policies and social impact) and consistency (internal and external) of this concept.

The finality of the educational system is the choice and construction of a career by young people. Thus, a new direction of research on the sustainability of young people's careers appears, in terms of the education system and the school path followed. After graduation, the sustainability of the education system is transferred, through results, to the sustainability of young people's careers.

Career is a profession, an occupation [18], an evolutionary succession of professional activities and professional positions that a person achieves through attitudes, knowledge and skills developed over time.

Career counseling is a process of global approach to the individual in all aspects of his personal, professional and social life and contains the provision of information, counseling and guidance services in order to support him —at any stage of life-for personal career development by taking appropriate decisions for themselves in the field of education, work and community life [19].

Operating the career concept is a challenge. What are the directly observable and measurable individual features that shape young people's career guidance [20]? In the specialized literature, the concept of career is operationalized by the following notions:

1. The Ikigai concept—choosing a path in life [21], with the four essential components: passion, mission, profession and vocation.

2. Well-being - the first step on the road (lifestyle). Well-being gives the energy and confidence to approach new perspectives, to accept challenges and changes [22-25]. It is the one who imprints quality of life [26-29].

3. Who am I?-The self, self-image, self-esteem [19].

4. Personality - Personality architecture [30-34], temperament, skills [35,36], character.

5. Intelligence-Theory of Multiple Intelligences, emotional intelligence, intra and interpersonal communication.

6. Motivation-Motivational factors, information and learning management [37].

7. Structure of thinking. The functions of thinking-attention and will.

8. Creativity-Intelligent creativity [38,39].

9. Ganbarimasu and shinkansen-How to have great ideas-Shinkansen; The luck of the beginner and the test of the winner-perseverance and patience-Ganbarimasu [21].

10. Profile personal career map [40].

The operationalization of the notion of career, based on the specialized literature, is illustrated in Figure 1. Among the concepts with which the notion of career operates are also the interests, on which the present study focuses. The personal interests of young people are a strong argument in choosing a career. 


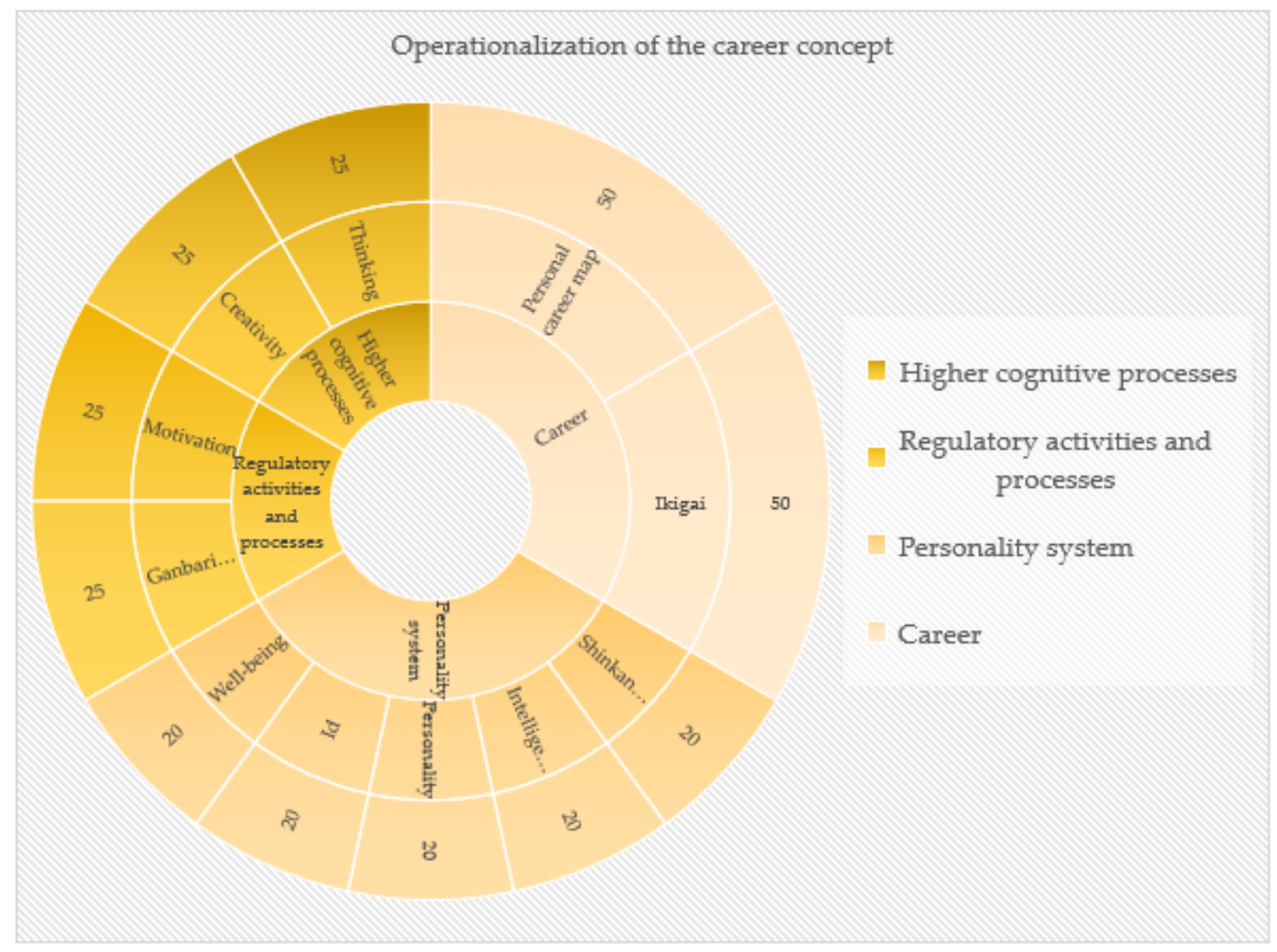

Figure 1. Operationalization of the career concept.

In order to study the interests of young people and the choice of career, it is interesting to observe the thinking mechanism that leads, in the end, to graduating from a certain school. A young person's school career is marked by questions and by answering them he will define his subsequent career.

We have begun the journey... the search for the meaning for which we exist...

Chronologically, our existence begins with the moment of conception and growth inside the mother. It is the moment when all the genetic information is in us; everything that our parents, grandparents and great-grandparents are, everything that could have been and everything that will be our descendants. In us are the ancestral fears of darkness and danger, in us are the matrix, the code for love, wisdom and goodness, as well as the search for light.

The man at the age of 2 tries to analyze himself in the mirror: "what do I look like, who am I, who is this self?" The adult asks, "What do you want to do when you grow up?" The 5-year-old wonders "What's up with me?" The adult returns: "What do you want to do when you grow up?" At a young school age (primary school) a person begins to prefer subjects, understands that he has a certain talent and is happy when he is appreciated. Then these preferences deepen and the first choice in the path of life appears... high school. It is a decision that opens or limits the future, a significant decision for the next period of time. The adult returns: "What do you want to do when you grow up?". We finally choose, then we set off again, until the next crossroads - college. We continue to choose based on what we like, what teachers tell us, the guidance of parents, based on our ancestral fears and desires, which limit us or make us overcome. The adult continues: "What do you want to do when you grow up?". We finish college, we find a job and we wonder... am I happy? The adult is silent... The man is silent... 
And in that silence, we ask ourselves: did I choose correctly, is this my place... I like to work but working in a factory is different than I imagined; I like to learn but working as a teacher is something else than I hoped...

Or in silence, I realize that I am happy, that I have chosen the right path to go...

Time passes, man does what he likes or dislikes and the phenomenon of hedonic adaptation appears-we get used to both good and evil and it becomes a part of us. Once we get used to it, the time comes when we want to change something in our lives. Many people choose to look for a new job. Where should I go? To that place where you feel that you are using your mind and soul, to the place that will bring you a comfortable material condition and will bring a benefit to those around you.

All the moments of life presented above are moments of searching for the direction of life, the direction of the road to go. The meaning of our choices is the well-being we feel and it shows us the positive or negative charge of our choices.

The question that is felt in us after the previous reflection is the following: How to find the meaning of my life? How quickly can you find the meaning for which you exist? These two questions will be further discussed in the form of the Ikigai concept.

How fast can you find the meaning of life? During childhood, we dreamed of superhero jobs or the jobs of special people, who impressed us around us. Parents, teachers, counselors, can guide us but most of the time, they do not know very well what our path could be. However, in adulthood we realize that what we like is, in fact, what we adore as children - to play in the kitchen (the future cook), to play in school (the future teacher), to open the cars (the future engineer), to clean and tidy (the future organized man). The book "All I really need to know I learned in kindergarten," written by Robert Fulghum [41], illustrates this idea very well. Everything I needed to know to find meaning in life I learned in the first seven years of home/kindergarten. Before being included in a more or less rigid education system, focused more or less on individual needs, we know how we are, we know what we like, we know and live our ikigai.

A sustainable career aims at a clear targeting, decisions taken by young people, in which the state, society and the family to invest in order to obtain results/profit. Training young people for the profession is a process that consumes the resources of society, the state and the family. Sustainable career training aims at allocating resources in a direction that will materialize through a job that produces directly observable and measurable effects on society. An overqualification in a job is an example of unsustainable use of resources invested in young people. Sustainable youth career management involves the involvement of all stakeholders: specialists, operators; teachers, resource beneficiaries; employers, owners; young graduates, administrators; families and civil society [42,43].

At the level of career management, sustainability can also be approached from the perspective of increasing the level of career preparation of students for clean, sustainable economies that achieve abrupt reductions in greenhouse gas emissions over the next thirty years $[44,45]$. Sustainable career management helps students aim for jobs that promote sustainability and make important contributions to the sustainable development of society.

The association of career with sustainability is not very common in the literature. At university level, career sustainability has an impact on both students and teachers [46]. In Romania, the standard cost per student allocated by the state increases annually but compared to the last 4 years, in 2020 it registered the smallest increase [47]. The allocation of resources to the education system is therefore growing at an ever-decreasing rate, which is why the career approach to sustainability is fully justified.

Some studies have led to the idea that a sustainable career can be built only by reconciling, rebalancing between previous expectations, during studies, on career and real career outcomes over time [48]. Another factor that determines a sustainable career is relationships among self-efficacy, transformational leadership, student employability and problem-based learning [49]. Other research that has taken place in the urban environment tends to associate sustainable careers with university training, technical training, devel- 
opment of knowledge, skills and abilities [50]. Sustainable careers also correlate with the ability to adapt and meet challenges [51].

Building a career has major implications for both the individual and society. An economically sustainable career involves costs during schooling, which should become an investment and bring profit through the professional activity of the young employee.

A determining factor in choosing a career is the interests of young people, along with factors related to the family and social environment in which the young person lives [52].

The interests of young people are currently being studied through personal profiles on different platforms [53]. Students' interests are also analyzed using the Holland Test, validated for different cultures [54-58].

The interests associated with the chosen field of university study appear in many international studies, either related to cultural characteristics or the type of study direction chosen: scientific or artistic. In the Romanian space, recent studies on students' interests, correlated with the chosen university field of study, are limited.

In this context, this paper aims to study the interests of young people in Romania and their correlation with the chosen field of university study. Moreover, this association between interests and field of study will be correlated with the concept of career sustainability. Such an analysis can provide directions on the educational and career guidance policies of young people, with an impact on the sustainability of the education system.

In Romania, career management is applied since kindergarten, adapted to the age level, in the form of personal development exercises [59]. For the final classes, when a certain educational path is chosen (8th and 12th grade), the career management is reduced to two meetings of the school counselor with the graduates (most of the times), having as subject personal development and not testing students' interests and skills and their effective career guidance. The legislation in the field does not grant the right to use test batteries for mental processes that influence the career management for school counselors.

Another limitation of school management in Romania is the choice of career based on the prestige of the school, the career of parents, the social pressures of the graduate's home geographical area and the lack of transparency of universities on the specifics of each study specialization.

The didactic activity within the university was the point of identification of the research problem. Many students are not satisfied with the choice of study specialization and some believe that they have chosen the wrong college.

Next, the study presents the research methods, the materials used, as well as the results obtained in the analysis of students' interests.

\section{Materials and Methods}

\subsection{Overview}

The purpose of the study is to analyze the interests of students in the Faculty of Engineering and to observe to what extent their interests correspond to the characteristics of the engineering profession, described by the Holland test.

The objectives of the study are:

1. Identify students' interests using the Holland Test.

2. Analysis of students' interests from the perspective of statistical questions.

3. Analysis of the first three interests of the students, who recorded the highest score, in the form of the summative code.

4. Correlation of the summative code with the three types of relations of the RIASEC marrow: adjacent, alternative, opposite.

5. Comparing the summative code of the RIASEC model with the interests required by the engineering profession.

\subsection{Participants}

Research population for this study is the youth studying at universities in Romania. The choosing of research sample was made through the proposal made by the authors to 
three universities in Romania. A number of six teachers distributed the questionnaire to all the students they had and in the end 373 students chose to participate in this study.

The study was attended by a number of 373 engineering students in the bachelor's degree (75\%) and master's degree (25\%), with different specializations-engineering 73\% and agricultural sciences, food engineering $27 \%$. Of the total subjects, $43 \%$ are male and $57 \%$ are female. Students are part of three university centers in Romania, in Sibiu (94\%), Cluj-Napoca (5\%) and Petroșani (1\%).

Group structure is characterized in the Figure 2 below.

Group structure
$87 \%$ of students are in the age group specific to the level of study, 19-26 years.

$55 \%$ have a job, of which more than half, $54 \%$, say that the position held is in the field studied to the faculty.

$58 \%$ live with their parents and $87 \%$ are unmarried. $67 \%$ have incomes between 1200 and 3200 lei.

$81 \%$ are satisfied with their career and $90 \%$ are satisfied with the life they have.

Figure 2. Group structure.

\subsection{Materials}

The Holland: Self-Directed Search (SDS) test, currently the best known and most used interest questionnaire, was used to identify students' interests [60-62]. Holland believes that people have different interests in working with people or objects and preferences for working with ideas or facts.

Holland's theory of vocational choice is a powerful framework for studying academic environments and student development in universities $[61,63]$. Testul Holland serves to define the degree of consistency in a personality or job environment configuration, as well as the degree of congruence between a person and their environment [64].

The Holland Test (SDS) is a tool used in self-assessment, which means that it is a tool that can also be used in self-administration, self-assessment and self-interpretation.

The test includes 120 questions with three answers: yes, no, indifferent. Each answer has a certain score: yes -2 points, indifferent -1 point, no- -0 points. The six SDS scales estimate the similarity of a person with each personality type, by indicating the three types with which a person fits best. The three-letter Summative Code summarizes the complexity of the human personality, while reducing certain issues inherent in the process of categorizing a person into a singular and unique typology [65]. The six types of interests are: realistic interests $(\mathrm{R})$; investigative interests $(\mathrm{I})$; artistic interests $(\mathrm{A})$; social interests (S); entrepreneurial interests (E); conventional type interests $(C)[66,67]$. These six types of interests form a pattern, named by the first letter of each interest: RIASEC model. For any type of personality, an occupation that has characteristics similar to that type gives the individual great satisfaction, because people are looking for professional environments and occupations that allow them to exercise their skills and abilities, to express their opinions and values [68].

A six-sided figure - a hexagon-is used to highlight the similarities and differences between the six types. The types that are close in hexagon have the greatest similarities. The following hexagon highlights the relationships between the six types. For example, the Realist and Investigative types tend to have similar interests but the Realist and Social types tend to be different. The Conventional type tends to be related to the Entrepreneurial 
and Realistic types, less similar to the Social and Investigative types but tends to be extremely different from the Artistic type and so on [69]. The smaller the distance between the personality type and the occupational type, the closer the relationship is. A person $\mathrm{R}$ and an occupation $R$ have the highest degree of congruence. A person $R$ in an $S$ function has the highest level of incongruence. The hexagonal model can be used to obtain four degrees or levels, of person-environment congruence or fit. The degree of consistency in the case of a person or an environment is defined by using the hexagonal model, as can be seen in Figure 3. Adjacent types on the hexagon are those that have the highest levels of consistency or are those that have common interests, personal dispositions or obligations. The types in opposition to the hexagonal model are those with the highest level of inconsistency, so they combine personal characteristics with unrelated occupations. An intermediate degree of consistency is defined by the alternative types in the hexagon. The consistency of the SDS profile is associated with a more stable employment history. It is assumed that this consistency is what leads to the realization of the vocation and clarity of personal goals [65].

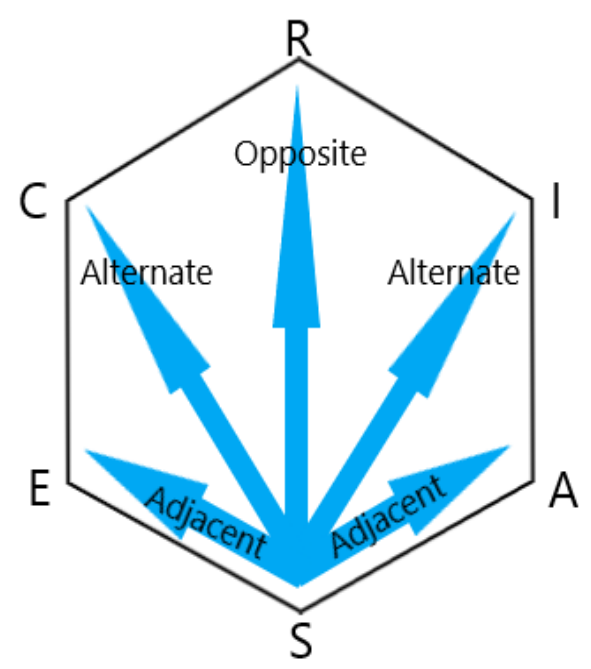

Figure 3. Type of personality. After [70].

The three RIASEC types [71,72] with the largest SDS codes are the Holland threeletter summative code. The code assigned to each person represents the summary of preferences - the combination of interests with the highest scores. The first letter of the code highlights the type with which the individual most closely resembles; the second letter highlights the next type it most closely resembles and so on. The types that do not appear in the three-letter code are the types that most closely resemble them. One can imagine the person's interests as a RIASEC pie, the size of the six slices being equal to the size of the SDS scores. The bigger the slice, the greater the interest in that field. Score differences of less than 8 points can be considered as showing similarities. Sometimes, the assigned codes have equal codes, which means that they are just as interesting for that person [68].

The Holland test was administered in the version translated into Romanian, a variant used by school and vocational guidance centers. It was administered online through Google Forms. Interpretation of the results was done using IBM SPSS Statistics v23.

In the questionnaire questions were added related to gender, university, faculty, field of study, year of study, age, job, if I live with my parents, marital status, if the job is in the faculty specialization, monthly income, if they are satisfied in their career and in their personal life. The purpose of these questions was also statistical to analyze whether there are correlations between students' interests and the factors mentioned above. 


\section{Results}

After applying the questionnaires and calculating the scores, the first three positions for each individual were retained and then the summative code was generated. The score recorded for the first place took values between 12 and 40, with an average of 31.35. Place number 2 and number 3 recorded values between 4 and 40 , with an average for place 2 of 27.65 and for place 3 of 23.97. It is observed that the maximum is identical for the three places and the minimum for the 2nd and 3rd place. It is a common situation, in which a person has several dominant interests, located at the same level. $23 \%$ of the research sample recorded a score between 36 and 38. High scores indicate people who have interests, strong passions, well defined, strongly motivating and energizing activity. 4 people registered the maximum score of 40 in the first 3 interests, representing $1 \%$ of the total research sample. $5.4 \%$ of the group recorded the same score for at least two interests in the first three positions. The percentage of $5.4 \%$ corresponds to the number of truly talented people in an organization, with above average intelligence, capable of superior performance in activity and strong intrinsic motivation.

The first place is occupied by the social type $-27.3 \%$, investigative $-25.2 \%$ and conventional and entrepreneurial $-18 \%$. The second place is occupied by the social type- $27.3 \%$, entrepreneurial-23.1\% and investigative by $19.6 \%$. The third place is occupied by the entrepreneurial type $-24.7 \%$, social $-22.8 \%$ and investigative $-16.4 \%$. It is observed that, contrary to the popular thinking that engineers are rigid, conventional and communicate with difficulty, having difficult social relationships with those around them, the main types of interests of engineering students are social, entrepreneurial and investigative. The artistic and realistic type records the lowest percentages, below $10 \%$. The Figure 4 below illustrates the percentage in which the interest rates for the first position were chosen.

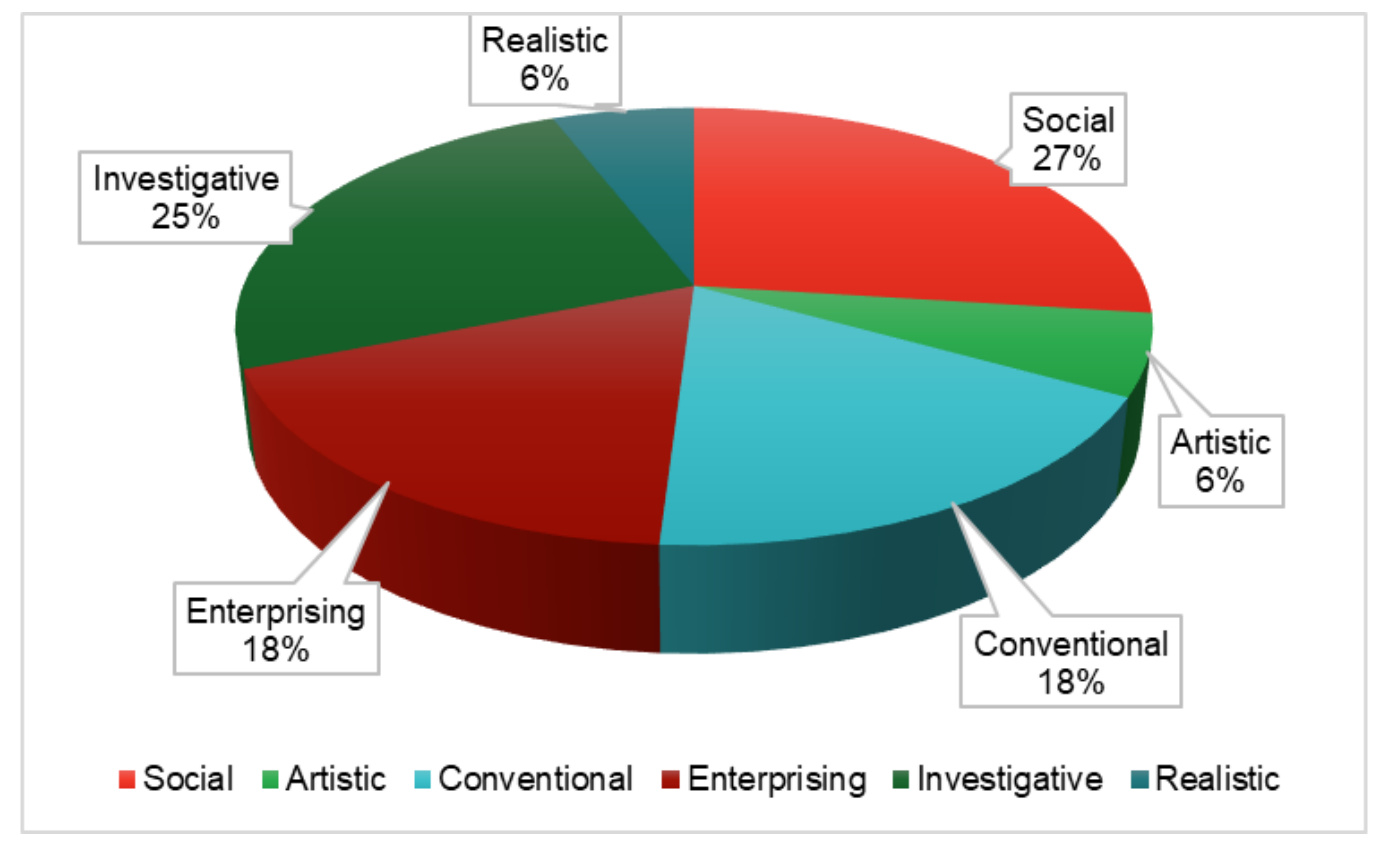

Figure 4. The main types of interests of engineering students.

The summative code represents the first three positions that recorded the highest scores. Out of 120 possible variants of arrangements, 87 variants were registered. Most elections had the code 253 (Conventional, Entrepreneurial, Social) with $6.7 \%$; code 435 (Investigative, Social, Entrepreneur) with $5.1 \%$ and code 345 (Social, Investigative, Entrepreneur) with $4.6 \%$. The most common numbers in the summative code marked with a red linethe area with the most cases, are 3, 5, 4 and 2, according to the Figure 5 below. 


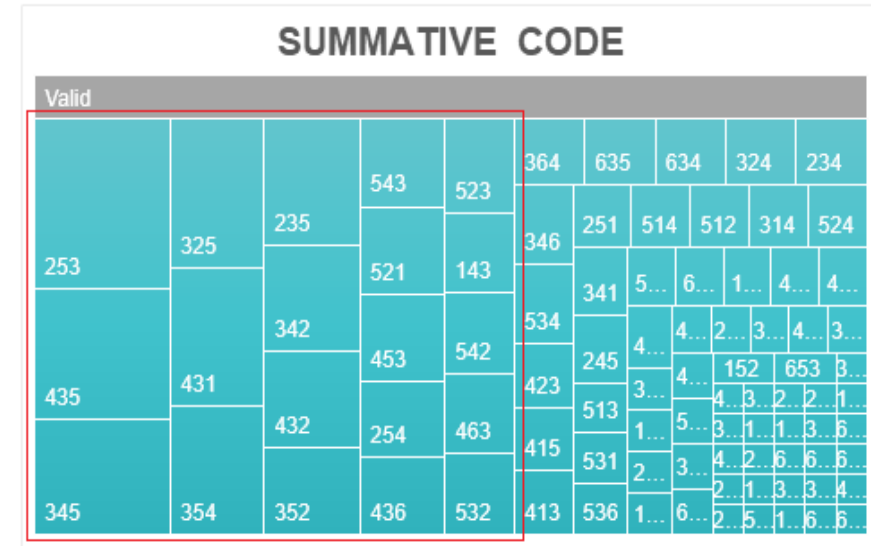

Figure 5. Visual representation of summative codes.

Among engineering students, the artistic type correlates most with the social, the conventional with the entrepreneur, the entrepreneur with the conventional, the investigative with the social, the realistic with the investigative, the social with the investigative. We notice that dichotomous relations are not reciprocal. The data obtained can also help in recruiting staff, to identify certain features based on others, to ensure a homogeneous, balanced, optimal team with superior performance.

\section{Discussion and Conclusions}

\subsection{Analysis of the Obtained Data}

Analyzing all the data obtained both in the Holland test and in the questions regarding the personal profile of the study participants, the Pearson correlation coefficient was calculated. Average level and strong correlations (0.400-0.994) were observed between the data below (Table 1).

Table 1. Correlations between obtain data.

\begin{tabular}{cccc}
\hline & & Rank II & Rank III \\
\hline Rank I & Pearson Correlation & $0.861^{* *}$ & $0.785^{* *}$ \\
Rank II & Pearson Correlation & $0.897^{* *}$ & \\
& & Rank I & \\
Summative code & Pearson Correlation & $0.994^{* *}$ & \\
\hline
\end{tabular}

** Correlation is significant at the 0.01 level (2-tailed).

Scores obtained for positions I, II and III—rank I, II, III are correlating each other. The correlation is studied in the hexagon of interests [68]. First place interest corelates with summative code.

\subsection{Data analysis According to Holland's Theory}

Results show that $42.4 \%$ of people show adjacent personality types, analyzed for the first two options of the code, which means they can choose to go on a single career path and $45 \%$ of people manifest alternative styles, so they are interested in related fields of study, implicitly work. These people can go in interdisciplinary directions of study, identify connections and relationships in the environment. The percentages are represented graphically in the Figure 6 below, as well as the codes related to the types of relationships. 


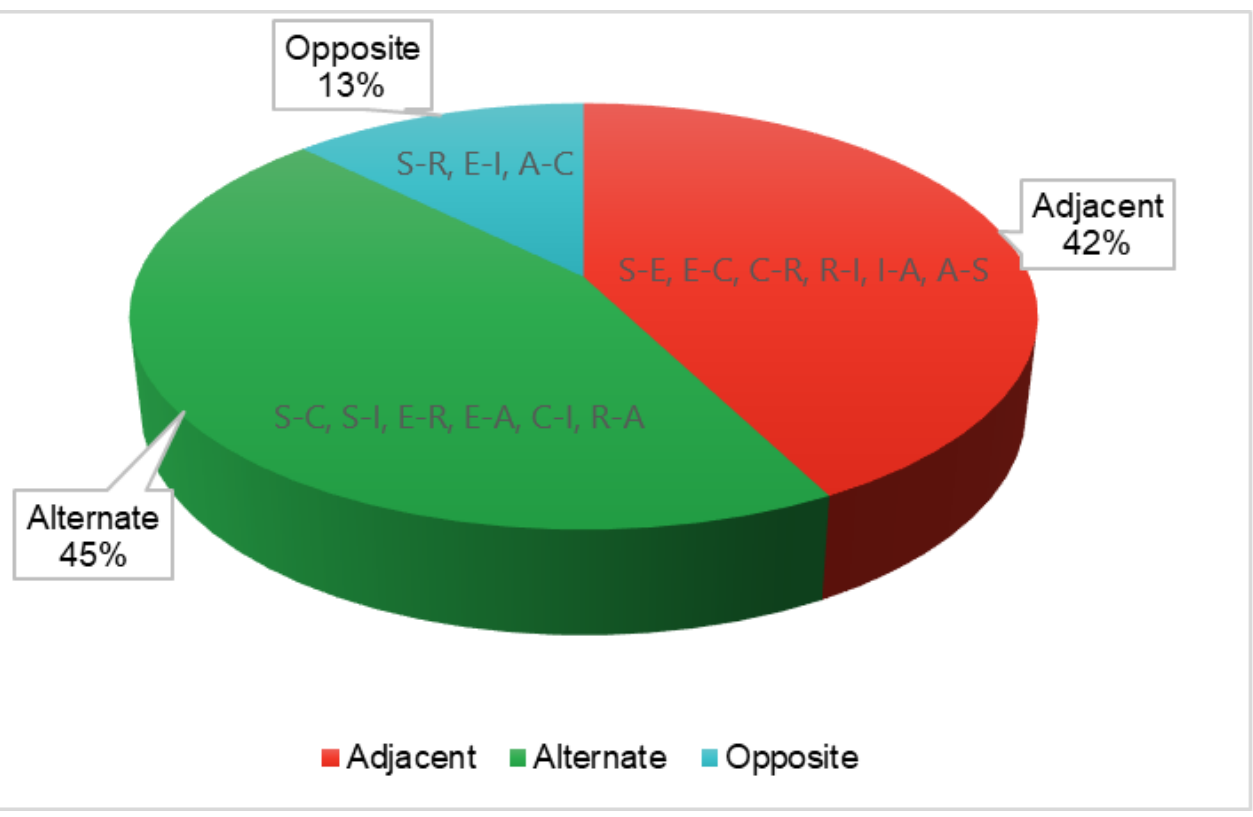

Figure 6. Percentage of styles related to the three types of relationships.

As shown in Figure 6, 12.6\% of people have interests in opposite fields, which gives them the opportunity to study and work in a wide range of fields. These people can sometimes be undecided, search hard and experiment until they stabilize in a certain field.

According to Holland's Theory, the profession of engineer, for which the research subjects are also prepared, is associated with the realistic type (mechanical engineer, in the electrical field), investigative (system engineer), entrepreneur (manager), conventional (IT engineer). In the perception of the Romanian society, a description of the engineering profession would be the following: it is characterized by the tendency to move towards activities that involve the manipulation of objects, tools, machines; he has technical ingenuity and practical spirit. He likes outdoor activities, he has difficulty expressing his feelings, he likes to build and repair. This is the broad description of the realistic type.

In the present study, there is an adjacent relationship between the social and entrepreneurial type, through which they have a common side of personality manifestation. It is interesting that the investigative type has an alternative relationship with the social type and an opposition relationship with the entrepreneurial one, so there are two structures of engineering students, which go in two different directions, as can be seen in the Figure 7:

- Social-investigative-10\%;

- Investigative-social-13.4\%;

- Entrepreneur-conventional-5\%;

- Conventional-entrepreneurial-10\%.
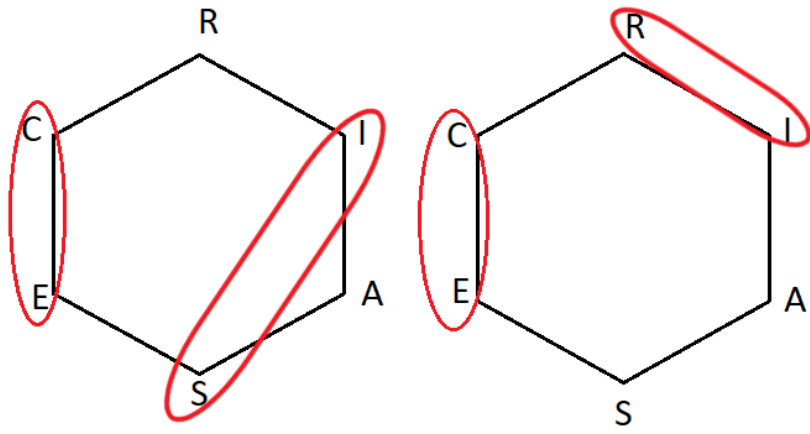

Figure 7. Comparison of the RIASEC model obtained in the research with that of Holland. 
Figure 7 compared the RIASEC model obtained from the analysis of engineering students' interests with the model proposed by Holland for the profile of engineers. It is observed that the profile obtained from the research focuses on the CE and SI directions, while Holland's model identifies the CE and RI directions. The realistic component of Holland's profile of engineers is replaced in the study by the social type.

However, the literature has also identified statements about the engineering profession that oppose Holland's Theory, more precisely the dominant interests chosen for the engineering profession. John Webster, an educator in Australia, said that engineering, in the real world, involves a lot of social skills. These include the ability to understand and achieve community goals, the ability to persuade decision-makers to invest in engineering projects, the ability to mobilize, organize and coordinate human, financial and physical resources, the ability to communicate. Reed a researcher in the field of education stated about engineers that what he learned in five years of studying engineering is that engineering relates in a way that is even funny and often neglected with people. It seems that the study validates their hypotheses, namely that engineering relates primarily to people and is strictly oriented towards them.

A study conducted on a group of students from Chinese university centers came to a similar conclusion, that certain constructs do not match the description in the Holland test and built a new self-report vocational interests scale [73,74]. Another study conducted in Costa Rica, involving a group of engineering students, concluded that the Holland test was weaker than other tests and indicators used to test vocational profile [75]. A group of researchers in Russia has identified problems with the Holland test in three directions, including vocational identity [76].

Other research in the field has recorded scores inversely proportional to students' artistic dimension, in relation to the social, innovative and entrepreneurial [77], the results applying to the present study. In another study, the social style was identified as belonging equally to the entrepreneurial-conventional and artistic cluster [78], so the social side appears associated with the typologies that exist in the results of the presented study.

\section{Conclusions}

In conclusion, among the research subjects, the four types that correlate with the engineering profession, associated with the adjacent types, represent a percentage of $29 \%$ of the research sample, which gives us the opportunity to say that they identify with the profession and chose it correctly, according to Holland's theory. Twenty seven percent manifest main characteristics specific to engineers, as well as other alternative typologies, which will allow them to work either in the field of study or in related fields.

A very high percentage, 33.5\%, does not fit the profile described by Holland for the engineering profession, being oriented towards the social or artistic part. This percentage is worryingly high, because at any time these people can choose either hybrid fields of activity in which to practice, focused on innovation $[79,80]$ or during college or after graduation, a new field of study. Changing fields of study, fluctuation in career decisions can be an expensive activity for the state, consuming resources and for the individual delays the time to reach the top of the career. For the individual, the wrong choice of career leads to increases stress and the degree of dissatisfaction and fulfillment towards oneself.

In conclusion, among the research sample there is a high number of students, $33.5 \%$, whose careers do not coincide with their interests. This leads to an unsustainable exploitation of individual resources and other stakeholders (family, state, university and pre-university education institutions). Early career orientation, by discovering personal interests and not with an emphasis on presenting professions can be a direction to approach the sustainable career of young people in Romania. Career guidance can be made by each teacher who comes into contact with the student throughout school life, by discovering special skills and special interests. Quality in education begins with the level of teacher training [81] which must be rethought in the sense of discovering the individual possibilities of youth and not necessarily the accumulation of information. A correct direction of 
pre-university education, towards discovering the interests of young people and their clear career orientation, can increase the sustainability of university education, as well as the quality of professional life of the individual.

\section{Study Implications and Limitations}

The study involved a number of 373 students from three university centers from Romania therefore the results of the study cannot be generalized to the entire population. Another limitation of the research is that the study is based on a Self-Directed Search test, which means that the data are the opinion of individuals about themselves and the characteristics analyzed are not measured objectively.

\section{Future Research Directions}

A future direction of research is to extend the study to a representative sample, so that the results of the study can be translated into suggestions on educational policies in Romania.

An interesting research topic for the future is the typology of Gardner's interests associated with the profile of engineers. To what extent has the engineering profession changed in recent years and how do these changes affect the profile of engineers' interests? The question starts from the present study and other studies presented, in which social interests are part of the RIASEC code, interests that are not part of the current profile of engineers described by Holland.

Another direction is the realization of a research in which to approach the students interests in relation to the type of intelligence, according to the Theory of Multiple Intelligences of Professor Howard Gardner.

Author Contributions: Conceptualization, L.-I.C. and M.L.B.; methodology, L.-I.C. and M.L.B.; software, L.-I.C. and M.L.B.; validation, L.-I.C. and M.L.B.; formal analysis, L.-I.C. and M.L.B.; investigation, L.-I.C. and M.L.B.; resources, L.-I.C. and M.L.B.; data curation, L.-I.C. and M.L.B.; writingoriginal draft preparation, L.-I.C. and M.L.B.; writing-review and editing, L.-I.C. and M.L.B.; visualization, L.-I.C. and M.L.B.; supervision, L.-I.C. and M.L.B.; project administration, L.-I.C. and M.L.B.; funding acquisition, L.-I.C. Both authors have read and agreed to the published version of the manuscript.

Funding: This research was funded by Lucian Blaga University of Sibiu, The Research centre for sustainable products and processes \& Hasso Plattner Foundation research action LBUS-RRC-2020-01.

Institutional Review Board Statement: The study did not required ethical approval.

Informed Consent Statement: Informed consent was obtained from all subjects involved in the study.

Data Availability Statement: The ethical conditions imposed by the standards were respected.

Conflicts of Interest: The authors declare no conflict of interest.

\section{References}

1. United Nations. The Rio Declaration on Environment and Development. In Proceedings of the Conference on Environment and Development, Rio de Janeiro, Brazil, 3-14 June 1992.

2. Bratu, I.A. Digitizing maps procedure for scientific forestry administration by GIS database. Case study: Rasinari forestry administration. In Proceedings of the 2019 International Conference on Energy and Environment (CIEM), Timisoara, Romania, 17-18 October 2019; pp. 95-98.

3. Bratu, I.A. Open source solutions to improve the quality of sustainable forest management. In Proceedings of the 9th International Conference on Manufacturing Science and Education-MSE 2019 "Trends in New Industrial Revolution", Sibiu, Romania, 21 August 2019; Volume 290, p. 11003. [CrossRef]

4. Blada, I.; Tănasie, S.; Dinu, C.; Bratu, I. Growth, straightness and survival at age 32 in a Pinus strobus x P. wallichiana F1 hybrid population (Experiment 1). Ann. For. Res. 2013, 56, 269-282.

5. Enescu, C.M.; Dincă, L.; Bratu, I.A. Chemical characteristics of the forest soils from Prahova County. Sci. Pap. Ser. Manag. Econ. Eng. Agric. Rural Dev. 2018, 18, 109-112.

6. Urdan, M.S.; Luoma, P. Designing Effective Sustainability Assignments: How and Why Definitions of Sustainability Impact Assignments and Learning Outcomes. J. Manag. Educ. 2020, 44, 794-821. [CrossRef]

7. Kopnina, H. Education for Sustainable Development Goals (ESDG): What Is Wrong with ESDGs, and What Can We Do Better? Educ. Sci. 2020, 10, 261. [CrossRef] 
8. Palumbo, R. Improving Health Professionals' Involvement Whilst Sustaining Work-Life Balance: Evidence from an Empirical Analysis. Sustainability 2020, 12, 9291. [CrossRef]

9. Borgonovi, E.; Adinolfi, P.; Palumbo, R.; Piscopo, G. Framing the Shades of Sustainability in Health Care: Pitfalls and Perspectives from Western EU Countries. Sustainability 2018, 10, 4439. [CrossRef]

10. Tanveer, M.; Hassan, S.; Bhaumik, A. Academic Policy Regarding Sustainability and Artificial Intelligence (AI). Sustainability 2020, 12, 9435. [CrossRef]

11. Mazon, G.; Ribeiro, J.M.P.; de Lima, C.R.M.; Castro, B.C.; Guerra, J.B. The promotion of sustainable development in higher education institutions: Top-down bottom-up or neither? Int. J. Sustain. High. Educ. 2020. [CrossRef]

12. Hernandez-Diaz, P.M.; Polanco, J.A.; Castano, S.M. Do sustainability practices influence university quality? A Colombian case study. Int. J. Sustain. High. Educ. 2020. [CrossRef]

13. Leuciuc, F.V.; Ghervan, P.; Popovici, I.M.; Benedek, F.; Lazar, A.G.; Pricop, G. Social and Educational Sustainability of the Physical Education of Romanian Students and the Impact on Their Physical Activity Level. Sustainability 2020, 12, 9231. [CrossRef]

14. Tlili, A.; Nascimbeni, F.; Burgos, D.; Zhang, X.L.; Huang, R.H.; Chang, T.W. The evolution of sustainability models for Open Educational Resources: Insights from the literature and experts. Interact. Learn. Environ. 2020. [CrossRef]

15. Nolasco, E.; Duraes, P.H.V.; Goncalves, J.P.; Oliveira, M.C.D.; de Abreu, L.M.; de Almeida, A.N. Characterization of solid wastes as a tool to implement waste management strategies in a university campus. Int. J. Sustain. High. Educ. 2020. [CrossRef]

16. Stein, S.; Andreotti, V.; Susa, R.; Ahenakew, C.; Cajkova, T. From "education for sustainable development" to "education for the end of the world as we know it". Educ. Philos. Theory 2020. [CrossRef]

17. Holdsworth, S.; Thomas, I. Competencies or capabilities in the Australian higher education landscape and its implications for the development and delivery of sustainability education. High. Educ. Res. Dev. 2020. [CrossRef]

18. Academia Română. DEX—Dictionarul Explicativ al Limbii Romane. Editia 2016; Univers Enciclopedic Gold: București, Romania, 2016.

19. Jigău, M. Consilierea Carierei. Compendiu de Metode și Tehnici; Sigma: București, Romania, 2007; p. 13.

20. Kell, H.J. Unifying Vocational Psychology's Trait and Social-Cognitive Approaches through the Cognitive-Affective Personality System. Rev. Gen. Psychol. 2018, 22, 343-354. [CrossRef]

21. Garcia, H.; Miralles, F. Metoda Ikigai; Humanitas: București, Romania, 2019.

22. Young, D.K.; Carpenter, D.; Maasberg, M. An Examination of Factors That Influence Students' IT Career Decisions. J. Comput. Inf. Syst. 2018, 58, 253-263. [CrossRef]

23. Assouline, M.; Meir, E.I. Metaanalysis of the relationship between congruence and well-being measures. J. Vocat. Behav. 1987, 31, 319-332. [CrossRef]

24. Bekhet, A.K.; Zauszniewski, J.A. Measuring Use of Positive Thinking Skills: Psychometric Testing of a New Scale. West. J. Nurs. Res. 2013, 35, 1074-1093. [CrossRef]

25. Boyraz, G.; Lightsey, O.R., Jr. Can Positive Thinking Help? Positive Automatic Thoughts as Moderators of the Stress-Meaning Relationship. Am. J. Orthopsychiatry 2012, 82, 267-277. [CrossRef]

26. Bratu, M.L.; Cioca, L.I. Managerial strategies for optimizing ergonomics in organizations, tailored to the personality of engineers, to improve the quality of life and security of employees. Qual. Access Success 2019, 20 (Suppl. 1), 31-36.

27. Bratu, M.L.; Cioca, L.I. Modelling Human Behaviour through Game Theory in Order to increase the Quality of Work and the Quality of Life of Employees through Managerial Strategies Appropriate to Individual and Group Personality. Qual. Access Success 2018, 19, 54-58.

28. Bratu, M.L.; Cioca, L.I. Adaptation of managerial style to the personality of engineers, in order to increase performance in the workplace. Pol. J. Manag. Stud. 2018, 17, 67-77. [CrossRef]

29. Giuseppe, S.; Ernesto, L.; Paola, M.; Rita, Z.; Zammitti, A. Relationship between Psychological Capital and Quality of Life: The Role of Courage. Sustainability 2020, 12, 5238.

30. Reardon, R.C. Self-Directed Search. Form R; Psychological Assessment Resource: Odessa, FL, USA, 1994.

31. Holland, J.L. Making Vocational Choices: A Theory of Vocational Personalities and Work Environments, 3rd ed.; Psychological Assessment Resources: Odessa, FL, USA, 1997.

32. Holland, J.L.; Fritzsche, B.; Powell, A. Self-Directed Search Technical Manual; Psychological Assessment Resources: Odessa, FL, USA, 1994.

33. Krishnamurthi, R.; Goyal, M. Automatic Detection of Career Recommendation Using Fuzzy Approach. J. Inf. Technol. Res. 2018, 11, 99-121. [CrossRef]

34. Erdogan, B.; Bauer, T.N. Enhancing career benefits of employee proactive personality: The role of fit with jobs and organizations. Pers. Psychol. 2005, 58, 859-891. [CrossRef]

35. Guide to the Use of GATB; U.S. Employment Service: Washington, DC, USA, 1952.

36. Fleishman, E.A. Ghidul Aptitudinilor Umane: Definirea și Măsurarea Aptitudinilor Umane; Sinapsis: Cluj-Napoca, Romania, 2008.

37. Ho, K.K.W.; Lo, P.; Chiu, D.K.W.; Kong, E.W.S.; Chen, J.C.C.; Zhou, Q.S.; Xu, Y.; Dalsgard, S. Intrinsic vs. extrinsic motivations of Master of Library and Information Science students: A cross-cultural comparative study. J. Librariansh. Inf. Sci. 2018, 50, 141-156. [CrossRef]

38. Mathis, E.L.; Bullock-Yowell, E.; Leuty, M.E.; Nicholson, B.C. Student congruence with academic major: Do hours worked and attitude affect satisfaction and success? Aust. J. Career Dev. 2017, 26, 142-152. [CrossRef]

39. Cioca, L.I.; Nerisanu, R. Enhancing Creativity: Using Visual Mnemonic Devices in the Teaching Process in Order to Develop Creativity in Students. Sustainability 2020, 12, 1985. [CrossRef] 
40. Verma, P.; Sood, S.K.; Kalra, S. Student career path recommendation in engineering stream based on three-dimensional model. Comput. Appl. Eng. Educ. 2017, 25, 578-593. [CrossRef]

41. Fulghum, R. All I Really Need to Know I Learned in Kindergarten; Ballantine Books: New York, NY, USA, 2004.

42. Bratu, I. Using GIS for sustainable forest management in Rasinari district, Sibiu County, Romania. Surv. Geol. Min. Ecol. Manag. 2016, 3, 615-622.

43. Hooley, T. Interventions in career design and education: Transformation for sustainable development and decent work. Br. J. Guid. Couns. 2020. [CrossRef]

44. Keniry, L.J. Equitable Pathways to 2100: Professional Sustainability Credentials. Sustainability 2020, 12, 2328. [CrossRef]

45. Garcia, J.; da Silva, S.A.; Carvalho, A.S.; Guerra, J.B. Education for Sustainable Development and Its Role in the Promotion of the Sustainable Development Goals. Manag. Ind. Eng. 2017, 1-18. [CrossRef]

46. Mackevica, L. The development of professional carreer of higher education establishment lecturers in the context of sustainability. In Scientific Articles of 7th International Conference: Person, Color, Nature, Music; Daugavpils University Academic Press: Daugavpils, Latvia, 2012; pp. 204-215.

47. Guvernul României. Hotărârea nr. 107/2020 Pentru Modificarea Hotărârii Guvernului nr. 72/2013 Privind Aprobarea Normelor Metodologice Pentru Determinarea Costului Standard per Elev/preșcolar și Stabilirea Finanțării de Bază a Unităților de învățământ Preuniversitar de Stat, Care se Asigură din Bugetul de Stat, din Sume Defalcate din T.V.A. Prin Bugetele Locale, pe Baza Costului Standard per Elev/Preșcolar. 2020. Available online: http://legislatie.just.ro/Public/DetaliiDocument/222806 (accessed on 2 September 2020).

48. Castro, M.R.; Van der Heiden, B.; Henderson, E.L. Catalysts in career transitions: Academic researchers transitioning into sustainable careers in data science. J. Vocat. Behav. 2020, 122. [CrossRef]

49. Liu, X.; Peng, M.Y.P.; Anser, M.K.; Chong, W.L.; Lin, B.Q. Key Teacher Attitudes for Sustainable Development of Student Employability by Social Cognitive Career Theory: The Mediating Roles of Self-Efficacy and Problem-Based Learning. Front. Psychol. 2020, 11. [CrossRef]

50. Curseu, P.L.; Semeijn, J.H.; Nikolova, I. Career challenges in smart cities: A sociotechnical systems view on sustainable careers. Hum. Relat. 2020. [CrossRef]

51. Di Maggio, I.; Ginevra, M.C.; Santilli, S.; Nota, L.; Soresi, S. The role of career adaptability, the tendency to consider systemic challenges to attain a sustainable development, and hope to improve investments in higher education. Front. Psychol. 2020, 11. [CrossRef]

52. Pellegrini, G.; Saracino, B. Adolescents and Scientific Careers. Interests, Scholastic Experiences and the Opinions of Italian Students. Sociol. Nauk. Tehnol. Sociol. Sci. Technol. 2018, 9, 86-100.

53. Stepanenko, A.A.; Shilyaev, K.S.; Rezanova, Z.I. Attribution of professional interests of social network users based on subjectoriented groups and personal page. Vestn. Tomsk. Gos. Univ. Filol. Tomsk State Univ. J. Philol. 2018, 52, 130-144. [CrossRef]

54. Aljojo, N. Choosing a Career Based Personality Matching: A Case Study of King Abdulaziz University. Int. J. Adv. Comput. Sci. Appl. 2016, 7, 215-221. [CrossRef]

55. Woods, S.A.; Patterson, F.C.; Wille, B.; Koczwara, A. Personality and occupational specialty an examination of medical specialties using Holland's RIASEC model. Career Dev. Int. 2016, 21, 262-278. [CrossRef]

56. Morgan, B.; de Bruin, G.P.; de Bruin, K. Constructing Holland's Hexagon in South Africa: Development and Initial Validation of the South African Career Interest Inventory. J. Career Assess. 2015, 23, 493-511. [CrossRef]

57. du Toit, R.; de Bruin, G.P. The structural validity of Holland's R-I-A-S-E-C model of vocational personality types for young black South African men and women. J. Career Assess. 2002, 10, 62-77. [CrossRef]

58. Einarsdottir, S.; Rounds, J.; AEgisdottir, S.; Gerstein, L.H. The structure of vocational interests in Iceland: Examining Holland's and Gati's RIASEC models. Eur. J. Psychol. Assess. 2002, 18, 85-95. [CrossRef]

59. Nicu, A. The Importance of Mastering Pedagogy Knowledge in Initial Teacher Training. Eur. Proc. Soc. Behav. Sci. 2017, 23, 772-780. [CrossRef]

60. Eggerth, D.E.; Bowles, S.M.; Tunick, R.H.; Andrew, M.E. Convergent validity of O*NET Holland code classifications. J. Career Assess. 2005, 13, 150-168. [CrossRef]

61. Cupani, M.; Azpilicueta, A.E.; Sialle, V. Testing social cognitive career choice model across Holland types in high school students. Rev. Esp. Orientac. Psicopedag. 2017, 28, 8-24.

62. Reardon, R.C. Enhancing Self-Help Career Planning Using Theory-Based Tools. J. Career Assess. 2017, 25, 650-669. [CrossRef]

63. Rocconi, L.M.; Liu, X.Q.; Pike, G.R. The impact of person-environment fit on grades, perceived gains, and satisfaction: An application of Holland's theory. High. Educ. 2020, 80, 857-874. [CrossRef]

64. Nistal, M.T.F.; Soto, J.K.M.; Zaragoza, F.A.P. The structural validity of Holland's and Gati's RIASEC models of vocational interests in Mexican students. Electron. J. Res. Educ. Psychol. 2019, 17, 707-730.

65. Boiangiu, C.C.; Racu, I. Corelația Dintre Interesele Ocupaționale şi Personalitate la Vârsta Adolescentă: Concepte, Metode, Rezultate [The Relationship between Occupational Interests and Personality from Adolescence: Concepts, Methods, Results]; Digital Institutional Repository: Bucharest, Romania, 2016; Volume 1, pp. 119-133.

66. Lemeni, G.; Miclea, M. Consiliere şi Orientare—Ghid de Educaţie Pentru Carieră; Editura ASCR: Cluj-Napoca, Romania, 2004.

67. Yang, Y.; Morris, M.L.; Protolipac, D.S. Simplified Chinese version of the Strong Interest Inventory (R): Structure and psychometric properties. J. Vocat. Behav. 2018, 108, 214-226. [CrossRef] 
68. Testul Holland, Biblioteca Respiro. 2017. Available online: https://respiro.ro/respiroteca/carti/testul-holland (accessed on 15 September 2020).

69. de John, H.L.; Powel, B.; Fritzsche, B.A.; SDS. SDS-Holland/Holland Self-Directed Search; O.S. Organizzazioni Speciali: Bucharest, Romania, 2009.

70. Nye, C.S.; Rounds, J.; Drasgow, F. Vocational Interests and Performance: A Quantitative Summary of Over 60 Years of Research. Perspect. Psychol. Sci. 2012, 7, 384-403. [CrossRef]

71. Bullock, E.E.; Andrews, L.; Braud, J. Holland's theory in a postmodern world: RIASEC structure and assessments in an international context. Career Plan. Adult Dev. J. 2009, 25, 29-58.

72. Darcy, M.U.A.; Terence, J.G. Circumplex structure of Holland's RIASEC interests across gender and time. J. Couns. Psychol. 2007, 54, 17-31. [CrossRef]

73. Li, J.; Xu, C.; Li, C.J.; Zhang, H.C. Construction of Vocational Interests Scale for Young Chinese. J. Pac. Rim Psychol. 2018, 12. [CrossRef]

74. Wong, C.S.; Wong, P.M. Validation of Wong's Career Interest Assessment Questionnaire and Holland's revised hexagonal model of occupational interests in four Chinese societies. J. Career Dev. 2006, 32, 378-393. [CrossRef]

75. Alfaro-Barquero, A.; Chinchilla-Brenes, S. Construction and validation of a vocational profile test for scientific and technological careers. Tecnol. Marcha 2017, 30, 138-149. [CrossRef]

76. Diomin, A.N.; Sedykh, A.B.; Sedykh, B.R. Standardization of the technique for measuring career self-determination. Russ. Psychol. J. 2017, 14, 151-170. [CrossRef]

77. Plhakova, A.; Dostal, D.; Zaskodna, T. Holland's typology of vocational interests in relation to domain-specific creativity. Ceskoslovenska Psychol. 2015, 59, 17-32.

78. Leung, S.A.; Hou, Z.J. The structure of vocational interests among Chinese students. J. Career Dev. 2005, 32, 74-90. [CrossRef]

79. Ochirbat, A.; Shih, T.K.; Chootong, C.; Sommool, W.; Gunarathne, W.K.T.M.; Wang, H.H.; Ma, Z.H. Hybrid occupation recommendation for adolescents on interest, profile, profile, and behavior. Telemat. Inform. 2018, 35, 534-550. [CrossRef]

80. Burke, R. Hybrid recommender systems: Survey and experiments. User Model. User Adapt. Interact. 2002, 12, 331-370. [CrossRef]

81. Nicu, A. Policy and practice of initial teacher training. Procedia Soc. Behav. Sci. 2015, 180, 80-86. [CrossRef] 